\section{Socioeconomic status throughout life and body mass index: a systematic review and meta-analysis}

\author{
Nível socioeconômico ao longo da vida e índice \\ de massa corporal: uma revisão sistemática \\ e metanálise
}

\author{
Luna Strieder Vieira 1 \\ Isabel Oliveira Bierhals 1 \\ Juliana dos Santos Vaz 1 \\ Fernanda de Oliveira Meller 2 \\ Fernando César Wehrmeister 1 \\ Maria Cecília Formoso Assunção 1
}

doi: 10.1590/0102-311X00125518

\begin{abstract}
This article aimed to systematically review the association between socioeconomic status according to the life course models and the body mass index (BMI) in adults. A review was performed following the guidelines of the PRISMA. The studies were identified in the MEDLINE/PubMed, LILACS and Web of Science databases. The eligible articles investigated the association between at least one life course model (risk accumulation, critical period or social mobility) and BMI. In order to assess the quality of the selected articles, the NOS checklist was applied to each study. Eleven articles were selected for the systematic review, and seven articles were selected for the meta-analysis. The average score and the median in the NOS checklist were 6.4, within a maximum possible score of 8 points. The most used model was social mobility. Regarding meta-analysis, there was association between lower life course socioeconomic status and BMI among women. BMI mean difference (MD) was higher among those who remained with low socioeconomic status throughout life when compared with those who maintained a high socioeconomic status (MD: 2.17, 95\%CI: 1.48; 2.86). Before that, the BMI MD was higher among those with upward mobility, compared with those who maintained a high socioeconomic status throughout life (MD: 1.20, 95\%CI: 0.73; 1.68). The risk of overweight was also higher among women who maintained low socioeconomic status (summary RR: 1.70, 95\%CI: 1.05; 2.74); however, according to the GRADE, the studies presented very low quality evidence. For men, no association was observed. Having low socioeconomic status sometime during life is associated with higher BMI in adulthood.
\end{abstract}

Review; Meta-analysis; Body Mass Index; Socioeconomic Status

\section{Correspondence}

L. S. Vieira

Universidade Federal de Pelotas.

Rua Marechal Deodoro 1160, Pelotas, RS 96020-220, Brasil.

luna.stri@gmail.com

1 Universidade Federal de Pelotas, Pelotas, Brasil. 2 Programa de Pós-graduação em Sáude Coletiva, Universidade do Extremo Sul Catarinense, Criciúma, Brasil. 


\section{Introduction}

It is well established that obesity is one of the most important risk factors for mortality and morbidity and that it has been increasing globally in all age groups 1,2. The prevalence of global obesity tripled between 1975 and $2014^{2}$. According to the World Health Organization (WHO), in 2014, an estimated over 1.9 billion adults (39\% of the adults aged 18 or older) were overweight and, out of these, over 600 million were obese (13\%) 2 .

The body mass index (BMI) is a simple index, calculated by dividing the weight in kilograms by the height squared in meters. It is commonly used to classify underweight, overweight and obesity in adults 3 .

In an attempt to capture the cumulative and dynamic nature of the socioeconomic status, several life course models have been developed. The social mobility model considers the process by which people move up or down the social hierarchy throughout their life cycle. This model presupposes that changes in the socioeconomic position can affect the adult's health 4 and considers both intragenerational (within the same generation) and intergenerational (between two or more generations) trajectories 5 . The socioeconomic status accumulation model refers to the continuation of the childhood social conditions through their life and assumes that environments and/or experiences accumulate over the years, with a dose-response effect - since the impact on an individual's health would increase as the number, duration and intensity of those exposures increased - and affects the risk of becoming sick in adulthood 4 . The critical period model presupposes that there are time windows within which exposure can cause irreversible effects in the structure and functions of organs and tissues, which in the future may trigger illnesses 4 .

Although several studies have tried to demonstrate the association between socioeconomic status and various health indicators, such as childhood and adulthood, particularly in certain phases of life $6,7,8,9,10,11,12$, very few studies have tried to use socioeconomic status throughout life as exposure for BMI in adulthood. Many studies have limited themselves to investigating the effect of the social conditions on only one life stage and, consequently, the temporal nature of this association has not been considered, leading to a partial explanation of how socioeconomic status contributes to health outcomes 13. Besides, there is no record of a systematic review that has evaluated the effect of socioeconomic status over time, encompassing the three life course models, on BMI in adulthood. Newton et al. 14 performed a systematic review and meta-analysis; however, the authors only evaluated a lifelong socioeconomic status model (social mobility) by comparing individuals who, throughout life, remained with low socioeconomic status with those who maintained a high socioeconomic status.

This systematic review aimed to identify longitudinal studies that have evaluated socioeconomic status through life during the life course models and verify its association with BMI. Moreover, it intended to identify the most used models and to summarize its data with a meta-analysis.

\section{Methods}

\section{Data sources and literature search}

This study is a systematic review, following the guidelines of the Preferred Reporting Items for Systematic Reviews and Meta-Analyses (PRISMA), a protocol that defines the main items that must be reported in systematic reviews and meta-analyses 15 . The identification of the articles was carried out by searching the LILACS, PubMed/MEDLINE and Web of Science databases, as well as by tracking down bibliographical references from the articles selected for analysis. The systematic review protocol was registered in the International Prospective Register of Systematic Reviews (PROSPERO; registration number: CRD42018093713).

The search was carried out from September 2017 to December 2017, with an update conducted in December 2018 that found no new publications, and included three groups of terms for identifying the articles. The first group comprised terms related to socioeconomic status: (life course epidemiology", "socioeconomic status", "socio-economic position", "socioeconomic trajectories", "changes of socioeconomic status", "socioeconomic position", "social mobility", "life course socioeconomic 
position", "risk accumulation", "critical period" and "life course models"). The second group consisted of terms related to body mass index ("obesity", "body mass index", "adiposity" and "body composition"). Finally, the third group comprised terms that outline the study's design ("cohort studies" and "longitudinal studies"). The Boolean operator "or" was used within each groups, whereas the operator "and" was used between the three groups. Only terms in English were used. The search was complemented by investigating the references from the selected articles.

The search strategy was limited to publications of original investigations conducted with human beings, but with no restrictions as for age, date and language. The articles found were transferred to the software EndNote (http://www.endnote.com/) for the reading of titles and abstracts, and for selecting full texts.

\section{Study selection and data extraction}

Two reviewers (I.O.B. and L.S.V.) selected the articles to be included in the review, and the disagreements between them were settled by a third reviewer (M.C.F.A.). The reviewers excluded articles which did not evaluate at least one of the life course models (critical period, risk accumulation and social mobility) with the BMI outcome, and those which did not assess BMI in adults or did not consider background and life experiences when assessing socioeconomic status, that is, those studies that did not measured socioeconomic status in at least two life phases.

Studies were included in the meta-analysis if they reported a quantitative estimate (e.g. odds ratio $(\mathrm{OR})$, relative risk (RR), mean BMI, prevalence) and standard errors or standard deviation (SD) or 95\% confidence interval $(95 \% \mathrm{CI})$ between life course socioeconomic status and BMI.

\section{Quality assessment}

The Newcastle-Ottawa Scale (NOS) checklist was applied to each study. The NOS assesses the quality of nonrandomized studies with case-control or cohort designs. The scale judges three perspectives: study groups selection, comparability of the groups and the assortment of exposure or outcome, providing a general score with values ranging from 0 to 916 . The NOS was applied independently by the two reviewers (I.O.B. and L.S.V.).

In addition to evaluating the methodological quality of the studies using the NOS, the GRADE (Grading of Recommendations, Assessment, Development and Evaluation) was used to summarize the general quality of the evidence. GRADE classifies the quality of evidence and the strength of recommendation provided by systematic reviews, scientific advice, and clinical guidelines 17,18 . It is a way of representing confidence in the provided information, by classifying the level of evidence and expressing the emphasis, so that a particular conduct is adopted or rejected in the case of clinical trial reviews. The starting point is the appreciation of the research design. Outcomes from randomized clinical trials started the evaluation with a high-quality score (4 points), while those generated by observational studies started as low quality ( 2 points). Next, a weighting is performed to decrease or increase the quality of evidence. Five factors may decrease the quality of evidence score and three factors may increase it 17 .

The risk of bias (lack of randomization, lack of allocation concealment, and lack of blinding), inconsistency (when there is significant and unexplained variability in results from different trials), indirect evidence, imprecision (when wide confidence intervals mar the quality of the data) and publication bias (when studies with "negative" findings remain unpublished) may decrease the quality of evidence score 17.

A large effect (when the effect is so large that bias common to observational studies cannot possibly account for the result), the dose-response relation (when the result is proportional to the degree of exposure) and all plausible biases only reducing an apparent treatment effect (when all possible confounders would only reduce the observed effect. Thus, it is likely that the actual effect is larger than the data suggests) may increase the quality of evidence score 17.

Using these criteria, the level of evidence was classified, among the four levels shown by the GRADE: high quality, moderate quality, low quality and very low quality. In high quality evidences, additional research is very unlikely to change the prevalence estimate shown by the systematic review. 
When the study has very low-quality evidence, its prevalence estimate is very uncertain, and new studies are necessary 17,18 .

\section{Statistical analysis}

To strengthen the study, a meta-analysis was conducted with the model of social mobility and the studied outcome. We performed meta-analyses regarding BMI mean difference (MD) in adulthood, making the following comparisons: individuals who continued in a low socioeconomic status category throughout life with individuals who continued in high socioeconomic status; individuals with upward mobility with individuals who remained in high socioeconomic status throughout life; and individuals with downward mobility with individuals with upward mobility throughout life. In addition, meta-analyses were performed regarding prevalence of obesity in adulthood, comparing individuals who, throughout life, remained in a low socioeconomic status category with those who remained in high socioeconomic status. For this, random-effects models were used.

We assessed heterogeneity across studies using the I2 statistic to approximate the proportion of total variation in the estimates due to between-study heterogeneity. All statistical analyses were performed using STATA software, version 12.1 (https://www.stata.com).

\section{Results}

\section{Article selection}

A total of 6,942 articles was identified. After excluding duplicates, 5,620 titles were screened, 53 articles were selected for full text assessment and 11 manuscripts were included in the review, although only seven articles were included in the meta-analysis. Of these four articles that were not included, one did not evaluate social mobility and three did not report data required for meta-analysis (Figure 1).

\section{General characteristics}

As for the general characteristics, the oldest publication dated from 2003; 2 articles were from middle-income countries 7,19 and 9 were from high-income countries 20,21,22,23,24,25,26,27,28. The size of the samples ranged from 623 to 13,701 individuals (Table 1). Concerning the quality assessment of the articles, the average score and the median in the NOS scale were 6.4 and 6.0, respectively, within a maximum possible score of 8 points. The greatest limitations in the assessed articles were: not describing differential losses, not indicating the rate of follow-up, inadequate adjustment or lack of adjustment for confounding variables and not describing the results by sex (see Supplementary Table: http://cadernos.ensp.fiocruz.br/site/public_site/arquivo/supl-table-e00125518_2905.pdf).

\section{Evaluation of the outcome}

The method used for analyzing the outcome was very heterogeneous among the articles: 7 articles assessed the outcome as BMI mean and standard deviation 7,19,22,23,24,25,27 and four articles assessed BMI by categorizing it in overweight and/or obesity $20,21,26,28$. In addition, the BMI categorizations were different: one study used the category "overweight" for BMI between $25-29.9 \mathrm{~kg} / \mathrm{m}^{2}$ and "obesity" for BMI $\geq 30 \mathrm{~kg} / \mathrm{m}^{2} 20$; one study assessed excess weight (BMI $\left.\geq 25 \mathrm{~kg} / \mathrm{m}^{2}\right) 2$; two studies used the category "overweight" for BMI 25-30kg/m² and "obesity" for BMI > 30kg/m²) 21,26 and one study assessed only "obesity" (BMI > 30kg/m²) 28 (Table 1).

\section{Exposure assessment}

The variables used for constructing the socioeconomic status variable through life were heterogeneous. The variables used included: level of education, occupation, family income, employment status and home ownership (Table 1). 


\section{Figure 1}

Illustration of literature search.

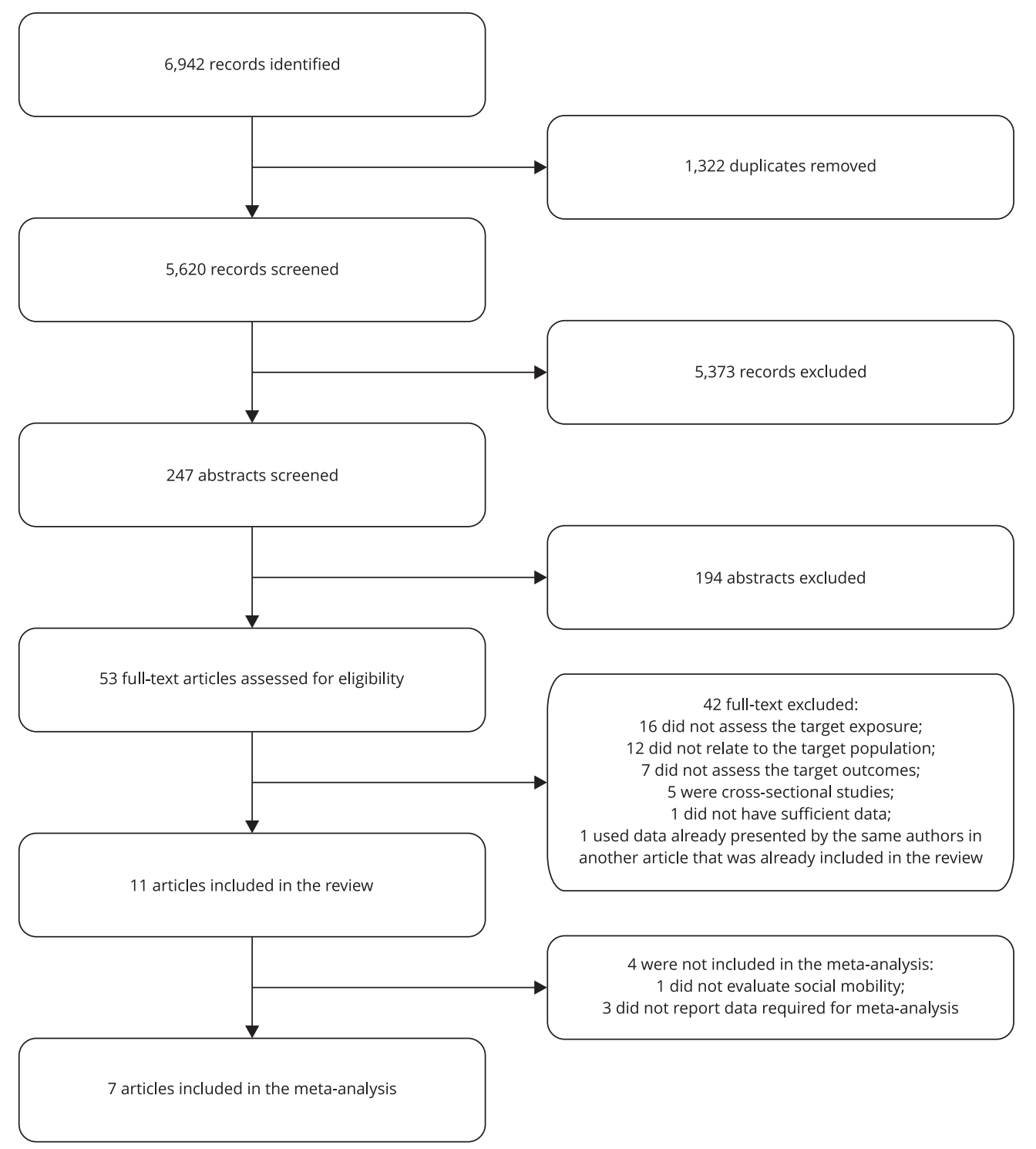

Concerning the assessed periods of socioeconomic status throughout life, seven studies evaluated socioeconomic status in childhood and adulthood (intergenerational mobility) 7,19,20,23,24,25,27; three assessed it from adolescence to adulthood (intergenerational mobility) 21,22,28; and one article assessed socioeconomic status from 40 to 60 years old (intragenerational mobility) 26 (Table 1).

As for "socioeconomic status throughout life", only two studies assessed the three life course models (risk accumulation, critical period and social mobility) simultaneously 25,26; seven studies assessed only social mobility 7,19,20,23,24,27,28; one study assessed critical period and socioeconomic status accumulation 22 and one study investigated social mobility and socioeconomic status accumulation 21 (Table 1). 
Table 1

Studies that assessed the relation between socioeconomic status throughout life and body mass index (BMI).

\begin{tabular}{|c|c|c|c|c|c|c|}
\hline $\begin{array}{l}\text { Study (Country/ } \\
\text { Year) }\end{array}$ & Sample & Life course model & Outcome & $\begin{array}{l}\text { Lifetime estimative } \\
\text { BMI }\end{array}$ & Main results & $\begin{array}{l}\text { NOS } \\
\text { score }\end{array}$ \\
\hline $\begin{array}{l}\text { Bernardi et al. } 19 \\
\text { (Brazil/2017) }\end{array}$ & $\begin{array}{l}\text { 2,063 individuals, } \\
\text { followed from birth } \\
\text { to } 23-25 \text { years old. } \\
\text { Age at outcome } \\
\text { assessment: between } \\
23 \text { and } 25 \text { years }\end{array}$ & $\begin{array}{l}\text { Social mobility from } \\
\text { childhood to adulthood. } \\
\text { In childhood, maternal } \\
\text { level of education; in } \\
\text { adulthood, participant's } \\
\text { level of education }\end{array}$ & $\begin{array}{l}\text { BMI: assessed } \\
\text { continuously }\end{array}$ & $\begin{array}{c}\text { Low vs. high } \\
\text { socioeconomic status } \\
\text { [mean BMI (SD)]: } \\
\text { Males: } 26.1 \text { (6.8) vs. } \\
25.4 \text { (6.7); Females: } \\
25.1 \text { (7.3) vs. } 22.5 \\
(6.7)\end{array}$ & $\begin{array}{l}\text { Among women born with } \\
\text { normal weight, the BMI was } \\
\text { higher in the group with } \\
\text { always low socioeconomic } \\
\text { status, as compared to the } \\
\text { group with always high } \\
\text { socioeconomic status. } \\
\text { Among those born with low } \\
\text { weight, BMI was higher in } \\
\text { the group with always low } \\
\text { socioeconomic status, as } \\
\text { compared to the group with } \\
\text { upward mobility. There was } \\
\text { no association for men }\end{array}$ & 8 \\
\hline $\begin{array}{l}\text { Savitsky et al. } 27 \\
\text { (Israel/2017) }\end{array}$ & $\begin{array}{l}\text { 1,132 individuals, } \\
\text { followed from birth to } \\
32 \text { years old. Age at } \\
\text { outcome assessment: } \\
32 \text { years }\end{array}$ & $\begin{array}{l}\text { Social mobility from } \\
\text { childhood to adulthood. } \\
\text { In childhood, parental } \\
\text { occupation was used; in } \\
\text { adulthood, participant's } \\
\text { level of education and } \\
\text { occupation }\end{array}$ & $\begin{array}{l}\text { BMI: assessed } \\
\text { continuously }\end{array}$ & $\begin{array}{c}\text { Low vs. high } \\
\text { socioeconomic } \\
\text { status: } \beta \text { (p-value): } \\
1.019(0.289)\end{array}$ & $\begin{array}{c}\text { Individuals with upward } \\
\text { mobility had, on average, } \\
\text { a higher BMI, as compared } \\
\text { to individuals with always } \\
\text { high socioeconomic status. } \\
\text { Analyses of downward social } \\
\text { mobility and always low } \\
\text { socioeconomic status were } \\
\text { not significant }\end{array}$ & 6 \\
\hline $\begin{array}{l}\text { Albrecht \& } \\
\text { Gordon-Larsen } 20 \\
\text { (United } \\
\text { States/2014) }\end{array}$ & $\begin{array}{l}\text { 13,701 individuals, } \\
\text { followed from 11/20 } \\
\text { to } 24 / 33 \text { years old. } \\
\text { Age at outcome } \\
\text { assessment: between } \\
24 \text { and } 33 \text { years }\end{array}$ & $\begin{array}{l}\text { Social mobility from } \\
\text { childhood to adulthood. } \\
\text { In childhood, parental } \\
\text { level of education was } \\
\text { used; in adulthood, } \\
\text { the participant's level } \\
\text { of education was } \\
\text { used. The mobility } \\
\text { was assessed in } \\
\text { three generations of } \\
\text { immigrants }\end{array}$ & $\begin{array}{l}\text { BMI: overweight } \\
\left(25.0-29.9 \mathrm{~kg} / \mathrm{m}^{2}\right) \\
\text { and obesity ( } \geq \\
\left.30 \mathrm{~kg} / \mathrm{m}^{2}\right)\end{array}$ & $\begin{array}{c}\text { Low vs. high } \\
\text { socioeconomic } \\
\text { status by immigrant } \\
\text { generation [mean } \\
\text { BMI (SE)]: First: } 26.1 \\
\text { (1.84) vs. } 24.7 \text { (1.57); } \\
\text { Second: } 28.3 \text { (1.25) } \\
\text { vs. } 26.0(1.03) \text {; Third: } \\
29.3(0.50) \text { vs. } 27.7 \\
(0.50)\end{array}$ & $\begin{array}{l}\text { In the first generation of } \\
\text { immigrants, individuals with } \\
\text { upward mobility had a lower } \\
\text { BMI mean as compared to } \\
\text { those who remained in the } \\
\text { low socioeconomic status } \\
\text { group. No association was } \\
\text { observed with the other } \\
\text { generations and with } \\
\text { downward and stable high or } \\
\text { medium mobility }\end{array}$ & 6 \\
\hline $\begin{array}{l}\text { Boylan et al. } 21 \\
\text { (Denmark/2014) }\end{array}$ & $\begin{array}{l}623 \text { adolescents. } \\
\text { Followed for } 20-22 \\
\text { years (from } 17 \text { to } 38 \\
\text { years old). Age at } \\
\text { outcome assessment: } \\
\quad 38 \text { years }\end{array}$ & $\begin{array}{c}\text { Socioeconomic } \\
\text { status accumulation } \\
\text { and social mobility } \\
\text { from adolescence } \\
\text { to adulthood. For } \\
\text { socioeconomic status in } \\
\text { adolescence, paternal } \\
\text { level of education } \\
\text { and occupation was } \\
\text { used; in adulthood, } \\
\text { the participant's level } \\
\text { of education and } \\
\text { occupation }\end{array}$ & $\begin{array}{l}\text { BMI: overweight } \\
\left(25-30 \mathrm{~kg} / \mathrm{m}^{2}\right) \text { and } \\
\text { obesity }(>30 \mathrm{~kg} / \\
\left.\mathrm{m}^{2}\right)\end{array}$ & $\begin{array}{c}\text { Low vs. high } \\
\text { socioeconomic status } \\
\text { [OR }(\mathrm{CI}) \text { ]: Males: } 1.0 \\
(0.3 ; 2.9) \text {; Females: } \\
2.8(0.9 ; 8.3)\end{array}$ & $\begin{array}{l}\text { Women with downward } \\
\text { socioeconomic status were } \\
\text { more likely to be overweight/ } \\
\text { obese as compared to } \\
\text { those who remained in } \\
\text { the high socioeconomic } \\
\text { status group. The OR of } \\
\text { overweight/obesity among } \\
\text { women who accumulated } \\
\text { low socioeconomic status } \\
\text { from } 17 \text { to } 38 \text { years of age } \\
\text { was } 3.6 \text { times higher than } \\
\text { those who accumulated high } \\
\text { socioeconomic status. There } \\
\text { was no association for men }\end{array}$ & 5 \\
\hline
\end{tabular}

(continues) 
Table 1 (continued)

\begin{tabular}{|c|c|c|c|c|c|c|}
\hline $\begin{array}{l}\text { Study (Country/ } \\
\text { Year) }\end{array}$ & Sample & Life course model & Outcome & $\begin{array}{l}\text { Lifetime estimative } \\
\text { BMI }\end{array}$ & Main results & $\begin{array}{l}\text { NOS } \\
\text { score }\end{array}$ \\
\hline $\begin{array}{l}\text { Padyab \& } \\
\text { Norberg } 26 \\
\text { (Sweden/2014) }\end{array}$ & $\begin{array}{c}\text { 3,340 individuals, } \\
\text { followed from birth to } \\
60 \text { years old. Age at } \\
\text { outcome assessment: } \\
60 \text { years }\end{array}$ & $\begin{array}{l}\text { Socioeconomic status } \\
\text { accumulation, social } \\
\text { mobility and critical } \\
\text { period. The three } \\
\text { models were assessed } \\
\text { with socioeconomic } \\
\text { status at 40, } 50 \text { and } \\
60 \text { years old. It was } \\
\text { assessed by the } \\
\text { participant's occupation }\end{array}$ & $\begin{array}{l}\text { BMI: assessed } \\
\text { continuously }\end{array}$ & $\begin{array}{l}\text { Low vs. high } \\
\text { socioeconomic status } \\
\text { [mean BMI (SD)]: } \\
\text { Males: } 26.1 \text { (3.5) vs. } \\
26.4 \text { (3.5); Females: } \\
\text { 26.6 (4.4) vs. } 25.3 \\
\text { (3.6) }\end{array}$ & $\begin{array}{l}\text { Women who kept a low } \\
\text { socioeconomic status } \\
\text { had a higher BMI average } \\
\text { than those who kept high } \\
\text { socioeconomic status. } \\
\text { Women with no accumulation } \\
\text { of socioeconomic status } \\
\text { disadvantage had a lower } \\
\text { BMI mean than those } \\
\text { with accumulation of } \\
\text { socioeconomic status } \\
\text { disadvantage. At each } \\
\text { increase of one unit in the } \\
\text { accumulation score, the BMI } \\
\text { increased by an average of } \\
0.44 \mathrm{~kg} / \mathrm{m}^{2} \text {. The critical period } \\
\text { model was not significant }\end{array}$ & 6 \\
\hline $\begin{array}{l}\text { Aitsi-Selmi et al. } 7 \\
\text { (Brazil/2013) }\end{array}$ & $\begin{array}{l}2,063 \text { individuals, } \\
\text { followed from birth } \\
\text { to } 23 / 25 \text { years old. } \\
\text { Age at outcome } \\
\text { assessment: between } \\
23 \text { and } 25 \text { years }\end{array}$ & $\begin{array}{l}\text { Social mobility from } \\
\text { childhood to adulthood } \\
\text { assessed by family } \\
\text { income }\end{array}$ & $\begin{array}{l}\text { BMI: assessed } \\
\text { continuously }\end{array}$ & $\begin{array}{l}\text { Low vs. high } \\
\text { socioeconomic status } \\
\text { [mean BMI (SD)]: } \\
\text { Males: } 24.8(4.6) \text { vs. } \\
25.4 \text { (4.7); Females: } \\
24.6 \text { (5.8) vs. } 22.6 \\
\text { (4.1) }\end{array}$ & $\begin{array}{c}\text { Women with upward } \\
\text { mobility and who kept a high } \\
\text { socioeconomic status had, } \\
\text { on average, lower BMl as } \\
\text { compared to those who kept } \\
\text { a low socioeconomic status. } \\
\text { There was no association for } \\
\text { men }\end{array}$ & 8 \\
\hline $\begin{array}{l}\text { Gustafsson } \\
\text { et al. } 22 \\
\text { (Sweden/2012) }\end{array}$ & $\begin{array}{c}863 \text { individuals, } \\
\text { followed from } 16 \text { to } \\
43 \text { years old. Age at } \\
\text { outcome assessment: } \\
\quad 43 \text { years }\end{array}$ & $\begin{array}{l}\text { Critical period assessed } \\
\text { from } 16 \text { to } 43 \text { years } \\
\text { old and socioeconomic } \\
\text { status accumulation } \\
\text { assessed by number } \\
\text { of times with low } \\
\text { socioeconomic status } \\
\text { (occupation) in all the } \\
\text { follow-ups }\end{array}$ & $\begin{array}{l}\text { BMI: assessed } \\
\text { continuously }\end{array}$ & $\begin{array}{l}\text { Accumulation ( } \mathrm{R} 2) \text { : } \\
\text { Males: } 1.0 \% \text { (age } 30 \\
\text { years); Females: } 1.0 \% \\
\text { (age } 16 \text { years) and } \\
4.6 \% \text { (age } 43 \text { years). } \\
\text { Critical period (low } \\
\text { socioeconomic status } \\
16 \text { years): } \beta(\mathrm{Cl}) \text { : } \\
\text { Females: mean BMI } \\
\text { 30 years: } 1.11 \text { (0.43; } \\
\text { 1.78); mean BMI } 43 \\
\text { years: } 2.14 \text { (1.23; } \\
3.06)\end{array}$ & $\begin{array}{l}\text { Among women, the } \\
\text { accumulation of } \\
\text { socioeconomic status } \\
\text { disadvantage was associated } \\
\text { with the increase in BMI } \\
\text { average in all ages studied. } \\
\text { For men, only at } 30 \text { years, } \\
\text { with positive association. } \\
\text { Among women, adolescence } \\
\text { was considered a critical } \\
\text { period for a higher BMI } \\
\text { average at } 30 \text { and } 43 \text { years } \\
\text { of age. For men, no critical } \\
\text { period was observed }\end{array}$ & 6 \\
\hline $\begin{array}{l}\text { Krzyzanowska } \\
\text { \& Mascie- } \\
\text { Taylor } 23 \\
\text { (England, } \\
\text { Scotland and } \\
\text { Wales/2011) }\end{array}$ & $\begin{array}{l}\text { 2,090 individuals, } \\
\text { followed from birth } \\
\text { to 33-40 years. Age at } \\
\text { outcome assessment: } \\
\text { between } 33 \text { and } 40 \\
\text { years }\end{array}$ & $\begin{array}{l}\text { Social mobility from } \\
\text { childhood to adulthood } \\
\text { assessed by paternal } \\
\text { occupation and } \\
\text { participant's occupation }\end{array}$ & $\begin{array}{l}\text { BMI: assessed } \\
\text { continuously }\end{array}$ & $\begin{array}{l}\text { Mean BMI difference } \\
\left(\mathrm{kg} / \mathrm{m}^{2}\right) \text { from non- } \\
\text { mobile reference } \\
\text { group. Downwardly } \\
\text { mobile: } 0.68 ; \text { Upward } \\
\text { mean: }-0.07\end{array}$ & $\begin{array}{l}\text { Individuals with downward } \\
\text { mobility had, on average, } \\
\text { a higher BMI as compared } \\
\text { to those without social } \\
\text { mobility, and individuals } \\
\text { with upward social mobility } \\
\text { had, on average, a lower BMI } \\
\text { as compared to individuals } \\
\text { without social mobility }\end{array}$ & 6 \\
\hline
\end{tabular}

(continues) 
Table 1 (continued)

\begin{tabular}{|c|c|c|c|c|c|c|}
\hline $\begin{array}{l}\text { Study (Country/ } \\
\text { Year) }\end{array}$ & Sample & Life course model & Outcome & $\begin{array}{l}\text { Lifetime estimative } \\
\text { BMI }\end{array}$ & Main results & $\begin{array}{l}\text { NOS } \\
\text { score }\end{array}$ \\
\hline $\begin{array}{l}\text { Murray et } \\
\text { al. } 25 \text { (United } \\
\text { Kingdom/2011) }\end{array}$ & $\begin{array}{l}\text { 3,035 individuals, } \\
\text { followed from birth to } \\
53 \text { years old. Age at } \\
\text { outcome assessment: } \\
53 \text { years }\end{array}$ & $\begin{array}{l}\text { Socioeconomic status } \\
\text { accumulation, social } \\
\text { mobility and critical } \\
\text { period. In childhood, } \\
\text { parental occupation } \\
\text { was used; in early } \\
\text { adulthood and late } \\
\text { adulthood, the } \\
\text { participant's occupation }\end{array}$ & $\begin{array}{l}\text { BMI: assessed } \\
\text { continuously }\end{array}$ & $\begin{array}{c}\text { Low vs. high } \\
\text { socioeconomic status } \\
\text { [mean BMI (SD)]: } \\
\text { Males: } 27.9 \text { (4.2) vs. } \\
26.7 \text { (3.8); Females: } \\
28.6(6.3) \text { vs. } 26.0 \\
(4.4)\end{array}$ & $\begin{array}{l}\text { Among women, the best } \\
\text { model was accumulation } \\
\text { of socioeconomic status } \\
\text { disadvantage, where at } \\
\text { each increase of one unit in } \\
\text { the score of accumulation } \\
\text { of socioeconomic status } \\
\text { disadvantage, BMI increased } \\
\text { by an average of } 0.91 \mathrm{~kg} / \mathrm{m}^{2} \\
\text { at } 53 \text { years. For men, the best } \\
\text { model was the critical period } \\
\text { (low socioeconomic status in } \\
\text { childhood), where individuals } \\
\text { with low socioeconomic } \\
\text { status in childhood had a } \\
\text { higher BMl average }\end{array}$ & 6 \\
\hline $\begin{array}{l}\text { Scharoun-Lee } \\
\text { et al. } 28 \text { (United } \\
\text { States/2009) }\end{array}$ & $\begin{array}{l}12,940 \text { adolescents } \\
\text { followed into young } \\
\text { adulthood (mean age } \\
=21.7 \text { years). Age at } \\
\text { outcome assessment: } \\
\text { mean age }=21.7 \\
\text { years }\end{array}$ & $\begin{array}{c}\text { Social mobility from } \\
\text { adolescence to } \\
\text { adulthood assessed } \\
\text { by parental material } \\
\text { endowments, skills, } \\
\text { knowledge, material, } \\
\text { human, and social } \\
\text { capital + own of above }\end{array}$ & $\begin{array}{c}\text { BMI: obesity (> } \\
\text { 30kg/m²). }\end{array}$ & $\begin{array}{c}\text { Low vs. high } \\
\text { socioeconomic status } \\
\text { [RR (CI)]: Males: } 1.18 \\
(0.82 ; 1.7) ; \text { Females: } \\
3.01(1.95 ; 4.66)\end{array}$ & $\begin{array}{l}\text { Women were } 3 \text { times more } \\
\text { likely to be obese if they } \\
\text { were in the persistent low life } \\
\text { course socioeconomic status } \\
\text { compared to high life course } \\
\text { socioeconomic status. There } \\
\text { was no association for men }\end{array}$ & 6 \\
\hline $\begin{array}{l}\text { Langenberg et } \\
\text { al. } 24 \text { (England, } \\
\text { Scotland and } \\
\text { Wales/2003) }\end{array}$ & $\begin{array}{l}\text { 1,299 individuals, } \\
\text { followed from birth to } \\
53 \text { years old. Age at } \\
\text { outcome assessment: } \\
53 \text { years }\end{array}$ & $\begin{array}{l}\text { Social mobility from } \\
\text { childhood to adulthood. } \\
\text { In childhood, parental } \\
\text { occupation was used; in } \\
\text { adulthood, participant's } \\
\text { occupation }\end{array}$ & $\begin{array}{l}\text { BMI: assessed } \\
\text { continuously }\end{array}$ & $\begin{array}{c}\text { Low vs. high } \\
\text { socioeconomic status } \\
\text { [mean BMI (SD)]: } \\
\text { Males: } 27.7 \text { (4.0) vs. } \\
26.8 \text { (3.9); Females: } \\
28.8 \text { (5.4) vs. } 26.1 \\
(5.6)\end{array}$ & $\begin{array}{l}\text { For both men and women, } \\
\text { those who maintained a low } \\
\text { socioeconomic status or had } \\
\text { upward mobility had a higher } \\
\text { BMI average as compared } \\
\text { to those who kept a high } \\
\text { socioeconomic status }\end{array}$ & 7 \\
\hline
\end{tabular}

CI: confidence interval; NOS: Newcastle-Ottawa Scale; OR: odds ratio; RR: relative risk; SD: standard deviation; SE: standard error.

\section{Social mobility}

Out of the seven articles that analyzed social mobility among women 7,19,21,24,25,26,28, five verified that women who continued with low socioeconomic status throughout life had a higher mean BMI 7,19,24,26 or higher prevalence of obesity 28 , and one study found that women with downward social mobility were more likely to be overweight or obese compared to those who maintained a high socioeconomic status throughout life 21 .

Among men, out of the seven studies that assessed social mobility 7,19,21,24,25,26,28, six did not find associations $7,19,21,25,26,28$. One study verified that men with low socioeconomic status throughout life had, on average, a higher BMI 24.

The forest plots of the meta-analyses of the BMI MD between individuals of both sexes who remained in a low socioeconomic status category and those who remained in a high socioeconomic status category throughout life are displayed in Figure 2. With regard to the BMI MD between men who remained in a low socioeconomic status category and those who remained in a high socioeconomic status category throughout life, there was no significant difference (MD: 0.38, 95\%CI: -0.34 ; 1.11). Among females, the mean BMI difference was higher among those who remained with low socioeconomic status compared with those who maintained a high socioeconomic status throughout 
BMI mean difference comparing individuals who continued in low socioeconomic status category with individuals who remained in high socioeconomic status.

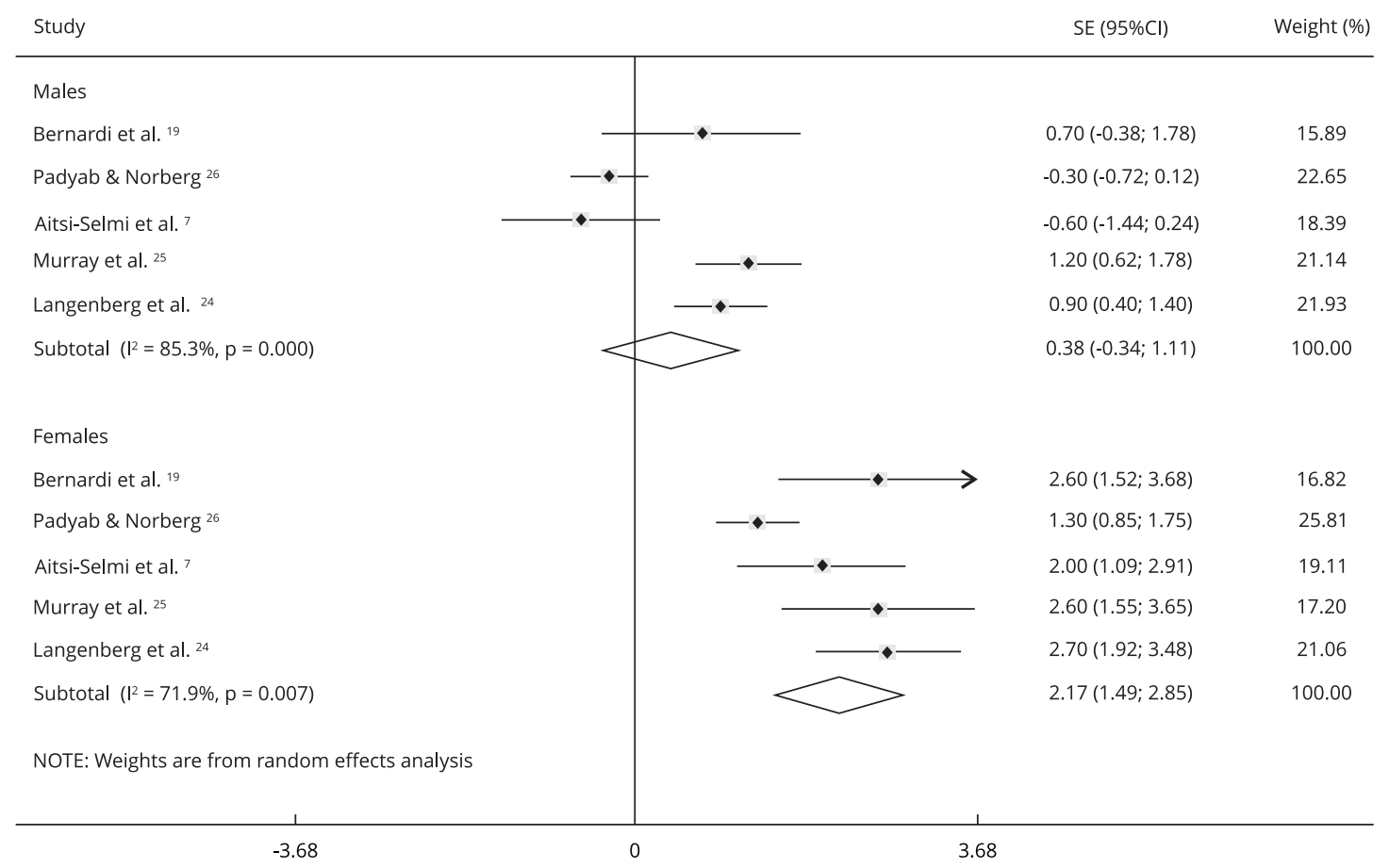

95\%Cl: 95\% confidence interval; BMI: body mass index; SE: standard error.

life; the pooled estimate of the mean BMI difference was 2.17 (95\%CI: 1.49; 2.85). Results for females were consistent across all included studies, while two studies for males reported lower mean BMI difference among lower life course socioeconomic status adults 7,26. There was evidence of significant heterogeneity across the included studies (males: $\mathrm{I}^{2}=85.3 \%$, p-value $=0.000$, and females: $\mathrm{I}^{2}=71.9 \%$, p-value $=0.007$ )

The forest plots of the meta-analyses of the BMI MD between individuals of both sexes with upward mobility and those who remained in a high socioeconomic status category throughout life are shown in Figure 3. With regard to the BMI MD between men with upward mobility and those who remained in a high socioeconomic status category throughout life, there was no significant difference (MD: 0.12, 95\%CI: -0.61; 0.86). Among females, the BMI MD was higher among those with upward mobility compared with those who maintained a high socioeconomic status throughout life; the pooled estimate of the BMI MD was 1.20 (95\%CI: $0.73 ; 1.68)$. There was evidence of significant heterogeneity across the included studies (males: $\mathrm{I}^{2}=83.1 \%$, p-value $=0.000$, and females: $\mathrm{I}^{2}=58.5 \%$, p-value $=0.047$ ).

Regarding the BMI MD with downward mobility and those with upward mobility among both sexes, the MD for men was 0.34 (95\%CI: -1.20; 0.52), and MD for women was 0.03 (95\%CI: -0.48; 0.54) (data shown in Supplementary Figure: http://cadernos.ensp.fiocruz.br/site/public_site/arquivo/ supl-figure-e00125518_3897.pdf).

In relation to the categorical data, only two studies were included in the meta-analysis (Figure 4). There was no significant difference in the RR of overweight by life course socioeconomic status among males (summary RR: 1.19, 95\%CI: 0.77; 1.85). Differently, females who continued with low 
Figure 3

BMI mean difference comparing individuals with upward mobility with individuals who continued in high socioeconomic status.

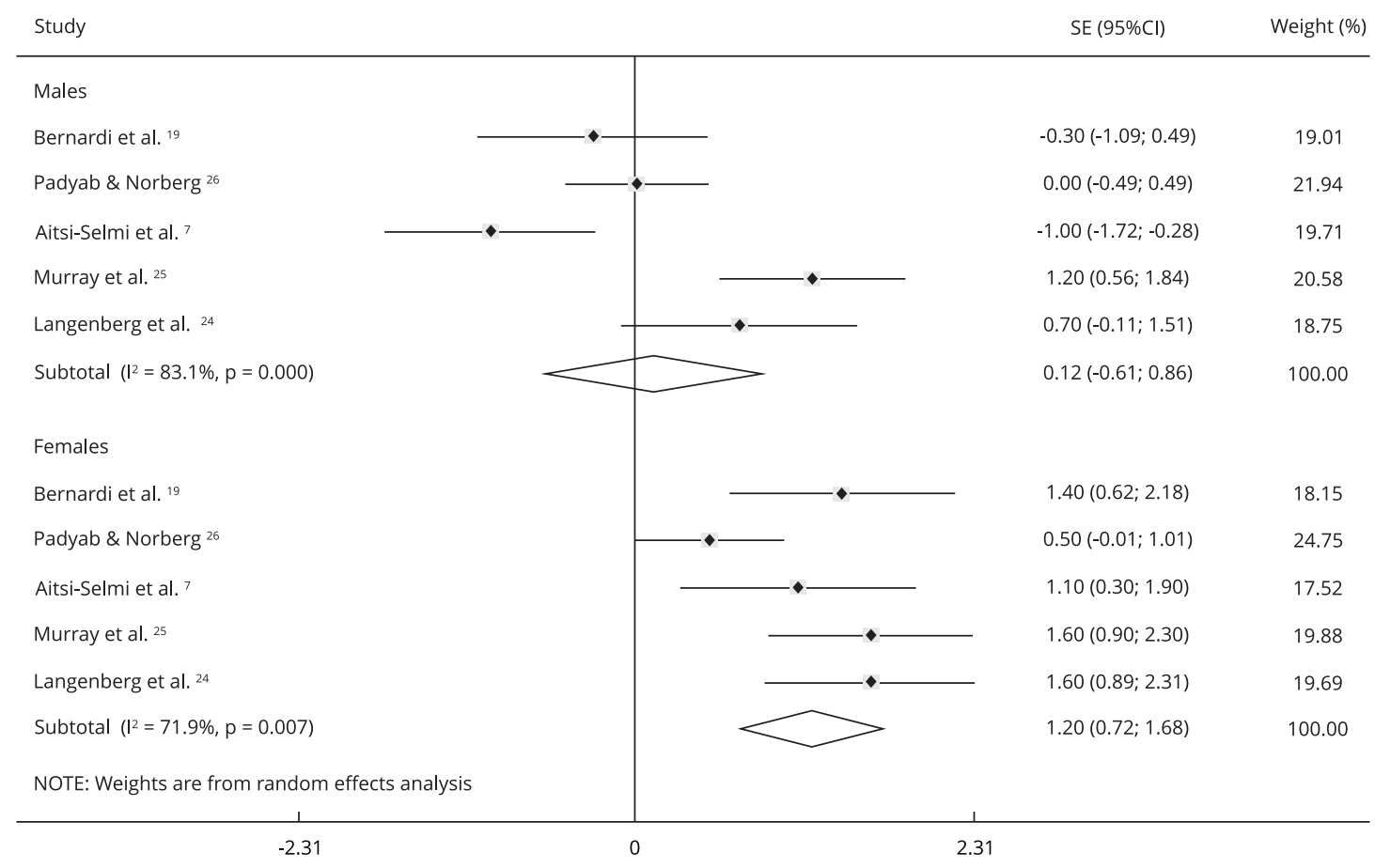

95\%Cl: 95\% confidence interval; BMI: body mass index; SE: standard error.

socioeconomic status had significantly higher relative risk of overweight compared those who maintained a high socioeconomic status throughout life (summary RR: 1.70, 95\%CI: 1.05; 2.74).

Regarding the GRADE assessment for the association between socioeconomic status throughout life and BMI MD and prevalence of obesity in adulthood, the association was considered of very low quality because of problems regarding study design and high statistical heterogeneity.

\section{Risk accumulation}

Risk accumulation was assessed in four articles 21,22,25,26. It was observed that a higher mean BMI and a higher prevalence of excess weight in adulthood were associated with women who had an accumulation of socioeconomic disadvantage throughout life, as compared to the women who did not 22,25,26.

Gustafsson et al. 22 showed that, among women with low socioeconomic status accumulation, aged 16 to 43 years, BMI was, on average, $0.8 \mathrm{~kg} / \mathrm{m}^{2}$ higher than women who did not accumulate low socioeconomic status $(\beta: 0.80,95 \% \mathrm{CI}: 0.47 ; 1.14)$. Boylan et al. 21 , also evaluating women, showed that the OR of overweight/obesity among those who accumulated low socioeconomic status, from 17 to 38 years of age, was 3.6 times greater $(95 \% \mathrm{CI}: 1.7 ; 7.7)$ than those who accumulated a high socioeconomic status. Murray et al. 25 showed that, among women, 1-unit increase in socioeconomic status score (a higher score means lower socioeconomic status) was associated with an increase of 0.91 in BMI at age 53 (95\%CI: 0.66; 1.61). Among men, out of the four studies, only Gustafsson et al. 22 found the same results observed among women, while the other three did not find any associations 21,25,26. Gustafsson et al. 22 showed that, among men with low socioeconomic status accumulation and between 16 to 30 years of age, BMI was, on average, $0.34 \mathrm{~kg} / \mathrm{m}^{2}$ higher than men who did not accumulate low socioeconomic status ( $\beta$ : 0.34, 95\%CI: 0.05; 0.63). 


\section{Figure 4}

Summary of relative risk for overweight comparing individuals who continued in low socioeconomic status category throughout life with individuals who remained in high socioeconomic status throughout life.

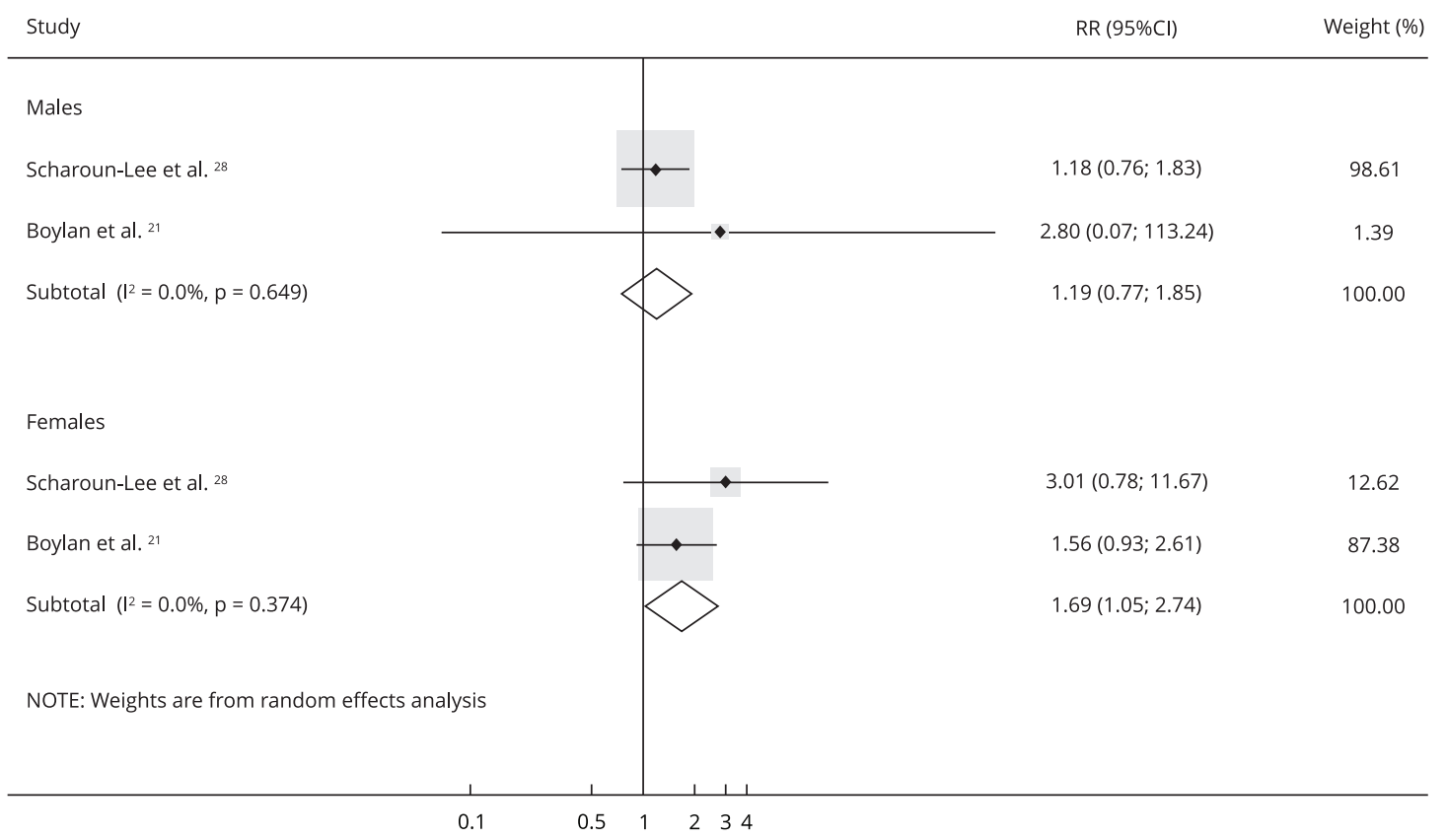

95\%Cl: 95\% confidence interval; RR: relative risk.

\section{Critical period}

The critical period model was analyzed in three studies 22,25,26. Out of those, Padyab \& Norberg 26 did not observe an association with BMI for any of the sexes. Gustafsson et al. 22 verified that, among women, adolescence (16 years old) was a critical period, that is, the BMI of adolescents with low socioeconomic status was, on average, $1.54 \mathrm{~kg} / \mathrm{m}^{2}$ times higher when compared with adolescents who did not show low socioeconomic status ( $\beta$ : 1.54, 95\%CI: 0.77; 2.32). Gustafsson et al. 22 found no association among men. Murray et al. 25 showed that, among men, childhood was a critical period, indicating that the BMI of boys with low socioeconomic status was, on average, $1.46 \mathrm{~kg} / \mathrm{m}^{2}$ times higher when compared to boys who did not present low socioeconomic status ( $\beta$ : $1.46,95 \% \mathrm{CI}$ : $1.14 ; 1.77$ ).

\section{Social mobility, risk accumulation and critical period}

Two studies assessed the three life course models 25,26 . Both of the studies found that the model that best explains the association between socioeconomic status throughout life and BMI, among women, is the risk accumulation model, as it was concluded that the more periods with low socioeconomic status throughout life, the higher the BMI 25,26. Among men, only one study observed an association 25 , showing that the critical period in childhood was the best model (the critical period model showed a match as good as the one of the saturated model, which includes all the hypotheses, and is better than the social mobility and risk accumulation) 30 . Therefore, men that were exposed to a low socioeconomic status in childhood showed, on average, a higher BMI in adulthood 25. 


\section{Discussion}

The BMI of women with upward mobility was, in general, higher than the BMI of those who kept a high socioeconomic status throughout life. Before that, women who remained with low socioeconomic status throughout life had a higher mean BMI or higher prevalence of obesity as compared to those who maintained a high socioeconomic status throughout life. Findings among men were less consistent. Newton et al. 14 found similar results despite having used longitudinal and cross-sectional studies in meta-analysis. This pattern is consistent with the hypothesis of risk accumulation, in which a greater duration of exposure to low socioeconomic status is associated with a bigger risk of high BMI 4. The risk accumulation may also be due to the clustering of exposures, for example, individuals with lower socioeconomic status are more likely to be born with low birth weight 31 , to have unhealthy diets 32 and to be less physically active during leisure time 33 and, therefore, had a greater risk of high BMI.

The fact that individuals with upward mobility show BMI values higher than individuals that kept a high socioeconomic status throughout life suggests that childhood might be a critical period. It is likely that these individuals with low socioeconomic status in childhood had less access to healthcare and information, as compared to those who kept a high socioeconomic status throughout life.

The evidence of heterogeneity among the included studies is an important point. Although it is not possible to perform subgroup analyses because of the small number of studies included in the metaanalyses, some divergent aspects stand out among the studies included in the meta-analysis, especially among men. While Murray et al. 25 and Langenberg et al. 24 showed a negative effect between socioeconomic status and mean BMI difference (men who maintained low socioeconomic status over time had a mean BMI difference greater than those who maintained high socioeconomic status throughout life), Padyab \& Norberg 26 and Aitsi-Selmi et al. 7 showed a positive effect between socioeconomic status and mean BMI difference (men who maintained low socioeconomic status throughout life had a MD in BMI lower than those who maintained high socioeconomic status throughout life). The converging points between Murray et al. 25 and Langenberg et al. 24 are as follows: both accompanied individuals from birth to 53 years of age, both studies were performed in high-income countries, both used occupation to assess the socioeconomic status and the results of the two studies were statistically significant. Aitsi-Selmi et al. 7 followed birth individuals at 23/25 years of age in a middle-income country, used income to assess socioeconomic status, and adjusted the analyses for birth weight. Padyab \& Norberg 26, meanwhile, followed the individuals from birth to 60 years of age and used occupation to evaluate the socioeconomic status. Padyab \& Norberg 26 and Aitsi-Selmi et al. 7 did not find statistically significant results.

Concerning the critical period, further research is necessary to elucidate the results, as only two out of the three articles evaluating the critical period found an association with BMI in adulthood, one found an association among women (critical period in adolescence) 22 and one among men (critical period in childhood) 25 .

About the different results between men and women, literature shows that it can be explained by differences in the eating behavior, parity, social pressure for women to be thin and occupation 34,35 . Assumpção et al. ${ }^{36}$, in a population-based study, evinced a better quality diet among women, as opposed to men, especially due to higher consumption of fruit, vegetables and milk and dairy. Concerning parity, there is evidence that women's level of education is inversely related to birth rate 37,38 . Since childbirth is associated with a long-term increase in obesity 39,40 , this could explain why the association between socioeconomic status and BMI is stronger among women than among men. In relation to social pressure, there is evidence that it is heavier against overweight and obesity in women and this pressure is even greater among women with a higher socioeconomic status 34,41 .

In addition, some evidence suggests that obesity is associated with occupation, where weight discrimination is comparable to the rates of color and age discrimination, especially among women. After using the microdata from the National Longitudinal Survey of Youth (NLSY), carried out in the United States, Cawley 42 reported that, among women, an increase in two standard deviations in weight is associated with a $9 \%$ decrease in salaries, an effect equivalent to one and half years of education or three years of work experience. When it comes to men, there is no consensus. Also based on 
the microdata from NLSY, Alauddin Majumber 43 found a positive effect of obesity on salary, whereas Pagan \& Dávila 44 did not find significant effects.

It is important to discuss the reverse causality of our findings. The meta-analysis conducted by Kim \& von dem Knesebeck 45 evaluated the bidirectionality of the socioeconomic level and BMI. The authors observed a consistent relation between obesity and subsequent income 45 . One possible explanation is the greater discrimination in workplaces, people with obesity have lower wages, spend more time unemployed, are classified as less qualified and work longer hours than people with healthy average weight 45,46,47,48. Consequently, discrimination may lead to adverse effects on the individual's health, such as impairment of psychosocial well-being, social isolation, lack of health care, binge eating, shame and guilt related to the body and development of obesity 49,50.

The strengths of this review include the search in multiple bibliographical bases, the manual revision of the list of references from the articles included, the independent search for duplicates to minimize selection errors, the use of a protocol following established guidelines and a scale to assess the quality of the articles, the exclusion of studies that measured retrospectively the childhood socioeconomic status (cross-sectional studies) and the fact that there is not any systematic review about socioeconomic status throughout life and BMI in adulthood that encompasses the three life course models.

An important limitation to be highlighted is the scale to evaluate the quality of the articles. If a study has a single major flaw (e.g. lack of adjustment for important confounders), that would decrease our confidence in its results, but it would still receive a high quality rating despite the fact that this methodological flaw alone should decrease substantially our trust in the study results. Another relevant limitation was the very low quality of evidence from the studies included in this review, mainly due to the observational design and several methodological limitations that compromised the quality of the evidence; thus, our results should be interpreted with caution.

It is recommended that future longitudinal studies evaluate the relation between the socioeconomic level throughout life and BMI in adult life with greater methodological rigor, considering the importance of not adjusting for mediating variables, but rather for confounding variables. Besides, more studies are needed to evaluate the critical period and risk accumulation models. About one third of the articles did not adjust the analyses for potential confusion factors 21,23,24,25 and adjusted their analyses for mediators such as alcohol drinking, smoking, physical activity and diet, which may have led to an underestimated effect measure 7,22,26. None of the studies indicated whether the individuals were different in relation to the participation in the study according to the assessed models, that is, whether individuals that kept a low socioeconomic status throughout life participated more than individuals that continued with a high socioeconomic status throughout life, which could lead to a selection bias. Another possible bias present in the assessed articles are the losses to follow-up, inherent to cohort studies. Moreover, the majority of the studies used only one life course model (social mobility), therefore the meta-analysis was only performed for this model.

Concerning the heterogeneity of the indicators used for evaluating socioeconomic status throughout life, it is possible to observe that, in high-income countries, the chosen indicators were occupation and level of education, while in middle-income countries, the preferred indicator was family income. Both middle-income studies were carried out in Brazil, a country that has had a widespread expansion in education, as well as several incentives for the access to higher education by those layers of society that were before left out. Therefore, it is reasonable to assume a reduction in the discriminating effect of the education level for younger generations and, consequently, a preference for family income as a more discriminating factor, given that occupation, in countries such as Brazil, poses limitations due to the lack of precision in measurement and classification 51. It was also found that a large number of the studies used dichotomous variables for socioeconomic status (high/low), which were usually limited to two points in time, such as childhood and adulthood. This may have led to a disregard of a possible important variation in socioeconomic status because a long period was not assessed. Studies on socioeconomic status throughout life that include three or more points in time enable the analysis of more informative trajectories than studies assessing only two points.

Maintaining a low socioeconomic status throughout life, particularly among women, is associated with higher BMI values. Studies that assess the causal mechanisms of this association are necessary for indicating interventions that can minimize this effect. 


\section{Contributors}

L. S. Vieira, I. O. Bierhals, J. Vaz, F. C. Wehrmeister, and M. C. F. Assunção contributed to the study design, data analysis and interpretation, article writing and critical review. F. Meller contributed to the analysis, review and final approval of the article.

\section{Additional informations}

ORCID: Luna Strieder Vieira (0000-0001-99468575); Isabel Oliveira Bierhals (0000-0002-87398669); Juliana dos Santos Vaz (0000-0002-2880767X); Fernanda de Oliveira Meller (0000-00021174-4721); Fernando César Wehrmeister (00000001-7137-1747); Maria Cecília Formoso Assunção (0000-0002-7767-8835).

\section{Acknowledgments}

This study was partially financed by the Brazilian Graduate Studies Coordinating Board (Capes; Finance Code 001).

\section{References}

1. NCD Risk Factor Collaboration. Worldwide trends in body-mass index, underweight, overweight, and obesity from 1975 to 2016 : a pooled analysis of 2416 population-based measurement studies in 128.9 million children, adolescents, and adults. Lancet 2017; 390:2627-42.

2. NCD Risk Factor Collaboration. Trends in adult body-mass index in 200 countries from 1975 to 2014: a pooled analysis of 1698 population-based measurement studies with 19.2 million participants. Lancet 2016; 387:137796.

3. World Health Organization. Body mass index - BMI. http://www.euro.who.int/en/ health-topics/disease-prevention/nutrition/ahealthy-lifestyle/body-mass-index-bmi (accessed on 29/Abr/2018).

4. Kuh D, Ben-Shlomo Y. A life course approach to chronic disease epidemiology: tracing the origins of ill-health from early to adult life. Oxford: Oxford University Press; 1997.

5. Pollitt RA, Rose KM, Kaufman JS. Evaluating the evidence for models of life course socioeconomic factors and cardiovascular outcomes: a systematic review. BMC Public Health 2005; 5:7.

6. Matthews KA, Kiefe CI, Lewis CE, Liu K, Sidney S, Yunis C. Socioeconomic trajectories and incident hypertension in a biracial cohort of young adults. Hypertension 2002; 39:772-6.

7. Aitsi-Selmi A, Batty GD, Barbieri MA, Silva AA, Cardoso VC, Goldani MZ, et al. Childhood socioeconomic position, adult socioeconomic position and social mobility in relation to markers of adiposity in early adulthood: evidence of differential effects by gender in the 1978/79 Ribeirao Preto cohort study. Int J Obes (Lond) 2013; 37:439-47.

8. Blane D, Harding S, Rosato M. Does social mobility affect the size of the socioeconomic mortality differential?: evidence from the Office for National Statistics Longitudinal Study. J R Stat Soc Ser A Stat Soc 1999; 162(Pt 1):59-70.

9. Brunner E, Shipley MJ, Blane D, Smith GD, Marmot MG. When does cardiovascular risk start? Past and present socioeconomic circumstances and risk factors in adulthood. J Epidemiol Community Health 1999; 53:757-64.

10. Malhotra R, Malhotra C, Chan A, Ostbye T. Life-course socioeconomic status and obesity among older Singaporean Chinese men and women. J Gerontol B Psychol Sci Soc Sci 2013; 68:117-27

11. Melchior M, Berkman LF, Kawachi I, Krieger $\mathrm{N}$, Zins M, Bonenfant S, et al. Lifelong socioeconomic trajectory and premature mortality (35-65 years) in France: findings from the GAZEL Cohort Study. J Epidemiol Community Health 2006; 60:937-44.

12. Poulton R, Caspi A, Milne BJ, Thomson WM, Taylor A, Sears MR, et al. Association between children's experience of socioeconomic disadvantage and adult health: a life-course study. Lancet 2002; 360:1640-5. 
13. Davey-Smith G, Lynch J. Life course approaches to socioeconomic differentials in health. In: Kuh D, Ben-Shlomo Y, editors. A life course approach to chronic disease epidemiology. Oxford: Oxford University Press; 2004. p. 77 115.

14. Newton S, Braithwaite D, Akinyemiju TF. Socio-economic status over the life course and obesity: systematic review and meta-analysis. PLoS One 2017; 12:e0177151.

15. Moher D, Liberati A, Tetzlaff J, Altman DG; PRISMA Group. Preferred reporting items for systematic reviews and meta-analyses: the PRISMA statement. Ann Intern Med 2009; 151:264-9, W64.

16. Wells G, Shea B, O'Connell D, Peterson J, Welch V, Losos M, et al. The Newcastle-Ottawa Scale (NOS) for assessing the quality of nonrandomized studies in meta-analyses. http://www.ohri.ca/programs/clinical_epi demiology/oxford.asp (accessed on 27/ Nov/2018).

17. Guyatt G, Oxman AD, Akl EA, Kunz R, Vist G, Brozek J, et al. GRADE guidelines: 1. Introduction-GRADE evidence profiles and summary of findings tables. J Clin Epidemiol 2011; 64:383-94.

18. Guyatt GH, Oxman AD, Vist GE, Kunz R, Falck-Ytter Y, Alonso-Coello P, et al. GRADE: an emerging consensus on rating quality of evidence and strength of recommendations. BMJ 2008; 336:924-6.

19. Bernardi JR, Goldani MZ, Pinheiro TV, Guimarães LSP, Bettiol H, da Silva AAM, et al. Gender and social mobility modify the effect of birth weight on total and central obesity. Nutr J 2017; 16:38.

20. Albrecht SS, Gordon-Larsen P. Socioeconomic gradients in body mass index (BMI) in US immigrants during the transition to adulthood: examining the roles of parental education and intergenerational educational mobility. J Epidemiol Community Health 2014; 68:842-8.

21. Boylan SM, Gill TP, Hare-Bruun H, Andersen LB, Heitmann BL. Associations between adolescent and adult socioeconomic status and risk of obesity and overweight in Danish adults. Obes Res Clin Pract 2014; 8:e163-71.

22. Gustafsson PE, Persson M, Hammarstrom A. Socio-economic disadvantage and body mass over the life course in women and men: results from the Northern Swedish Cohort. Eur J Public Health 2012; 22:322-7.

23. Krzyzanowska M, Mascie-Taylor CG. Intraand intergenerational social mobility in relation to height, weight and body mass index in a British national cohort. J Biosoc Sci 2011; 43:611-8.

24. Langenberg C, Hardy R, Kuh D, Brunner E, Wadsworth M. Central and total obesity in middle aged men and women in relation to lifetime socioeconomic status: evidence from a national birth cohort. J Epidemiol Community Health 2003; 57:816-22.
25. Murray ET, Mishra GD, Kuh D, Guralnik J, Black S, Hardy R. Life course models of socioeconomic position and cardiovascular risk factors: 1946 birth cohort. Ann Epidemiol 2011; 21:589-97.

26. Padyab M, Norberg M. Socioeconomic inequalities and body mass index in Vasterbotten County, Sweden: a longitudinal study of life course influences over two decades. Int J Equity Health 2014; 13:35.

27. Savitsky B, Manor O, Friedlander Y, Burger A, Lawrence G, Calderon-Margalit R, et al. Associations of socioeconomic position in childhood and young adulthood with cardiometabolic risk factors: the Jerusalem Perinatal Family Follow-Up Study. J Epidemiol Community Health 2017; 71:43-51.

28. Scharoun-Lee M, Kaufman JS, Popkin BM, Gordon-Larsen P. Obesity, race/ethnicity and life course socioeconomic status across the transition from adolescence to adulthood. J Epidemiol Community Health 2009; 63:133-9.

29. Heraclides A, Brunner E. Social mobility and social accumulation across the life course in relation to adult overweight and obesity: the Whitehall II study. J Epidemiol Community Health 2010; 64:714-9.

30. Mishra G, Nitsch D, Black S, De Stavola B, Kuh D, Hardy R. A structured approach to modelling the effects of binary exposure variables over the life course. Int J Epidemiol 2009; 38:528-37.

31. Martinson ML, Reichman NE. Socioeconomic inequalities in low birth weight in the United States, the United Kingdom, Canada, and Australia. Am J Public Health 2016; 106:748-54.

32. Darmon N, Drewnowski A. Does social class predict diet quality? Am J Clin Nutr 2008; 87:1107-17.

33. da Silva ICM, Mielke GI, Bertoldi AD, Arrais PSD, Luiza VL, Mengue SS, et al. Overall and leisure-time physical activity among Brazilian adults: National Survey Based on the Global Physical Activity Questionnaire. J Phys Act Health 2018; 15:212-8.

34. Finkelstein EA, Ruhm CJ, Kosa KM. Economic causes and consequences of obesity. Annu Rev Public Health 2005; 26:239-57.

35. Senese LC, Almeida ND, Fath AK, Smith BT, Loucks EB. Associations between childhood socioeconomic position and adulthood obesity. Epidemiol Rev 2009; 31:21-51.

36. Assumpção D, Domene SMA, Fisberg RM, Canesqui AM, Barros MBA. Diferenças entre homens e mulheres na qualidade da dieta: estudo de base populacional em Campinas, São Paulo. Ciênc Saúde Colet 2017; 22:347-58.

37. Kravdal $\varnothing$, Rindfuss RR. Changing relationships between education and fertility: a study of women and men born 1940 to 1964 . Am Sociol Rev 2008; 73:854-73.

38. United Nations. World population monitoring, 2003: population, education and development. New York: United Nations; 2005. 
39. Hajiahmadi M, Shafi H, Delavar MA. Impact of parity on obesity: a cross-sectional study in Iranian women. Med Princ Pract 2015; 24:704.

40. Li W, Wang Y, Shen L, Song L, Li H, Liu B, et al. Association between parity and obesity patterns in a middle-aged and older Chinese population: a cross-sectional analysis in the Tongji-Dongfeng cohort study. Nutr Metab (Lond) 2016; 13:72.

41. Su D, Esqueda OA, Li L, Pagan JA. Income inequality and obesity prevalence among OECD countries. J Biosoc Sci 2012; 44:417-32.

42. Cawley J. The impact of obesity on wages. J Hum Resour 2004; 39:451-74.

43. Alauddin Majumder M. Does obesity matter for wages? Evidence from the United States. Economic Papers 2013; 32:200-17.

44. Pagan JA, Dávila A. Obesity, occupational attainment, and earnings. Soc Sci Q 1997; 78:756-70

45. Kim TJ, von dem Knesebeck O. Income and obesity: what is the direction of the relationship? A systematic review and meta-analysis. BMJ Open 2018; 8:e019862.
46. Baum 2nd CL, Ford WF. The wage effects of obesity: a longitudinal study. Health Econ 2004; 13:885-99.

47. Flint SW, Cadek M, Codreanu SC, Ivic V, Zomer C, Gomoiu A. Obesity discrimination in the recruitment process: "you're not hired!". Front Psychol 2016; 7:647.

48. Han E, Norton EC, Powell LM. Direct and indirect effects of body weight on adult wages. Econ Hum Biol 2011; 9:381-92.

49. Mensinger JL, Tylka TL, Calamari ME. Mechanisms underlying weight status and healthcare avoidance in women: a study of weight stigma, body-related shame and guilt, and healthcare stress. Body Image 2018; 25:13947.

50. Puhl R, Suh Y. Health consequences of weight stigma: implications for obesity prevention and treatment. Curr Obes Rep 2015; 4:182-90.

51. Alves MTG, Soares JF. Medidas de nível socioeconômico em pesquisas sociais: uma aplicação aos dados de uma pesquisa educacional. Opin Pública 2009; 15:1-30. 


\section{Resumo}

Este trabalho teve como objetivo realizar uma revisão sistemática da associação entre nível socioeconômico de acordo com os modelos de curso de vida e indice de massa corporal (IMC) em adultos. Foi realizada uma revisão com base nas diretrizes PRISMA. Os estudos foram identificados nas bases de dados MELINE/PubMed, LILACS e Web of Science. Os artigos elegíveis investigaram a associação entre pelo menos um modelo de curso de vida (acúmulo de riscos, período crítico ou mobilidade social) e IMC. Para avaliar a qualidade dos artigos selecionados, a lista de critérios NOS foi aplicada a cada estudo. Foram selecionados 11 artigos para a revisão sistemática e sete artigos para a metanálise. A pontuação média e a mediana na lista NOS foram 6,4, dentro de uma pontuação possível de 8 . O modelo mais utilizado foi o da mobilidade social. Na metanálise, entre mulheres, houve associação entre nível socioeconômico ao longo da vida e IMC. A diferença média (DM) no IMC foi maior entre indivíduos que permaneceram com nível socioeconômico baixo ao longo da vida, comparado aos que mantiveram nivel socioeconômico alto (DM: 2,17; IC95\%: 1,48; 2,86). Antes disso, a DM no IMC foi maior entre indivíduos com mobilidade ascendente, comparado àqueles que mantiveram nível socioeconômico alto ao longo da vida (DM: 1,20; IC95\%: 0,73; 1,68). $O$ risco de sobrepeso também foi maior entre $m u$ lheres que mantiveram nivel socioeconômico baixo (RR sumário: 1,70; IC95\%: 1,05; 2,74); porém, de acordo com os critérios GRADE, os estudos apresentaram evidências de qualidade muito baixa. Não foi observada associação em homens. O nível socioeconômico baixo em algum momento da vida está associado ao IMC mais alto na vida adulta.

Revisão; Metanálise; Índice de Massa Corporal; Situação Socioeconômica

\section{Resumen}

Este trabajo tuvo como objetivo realizar una revisión sistemática de la asociación entre nivel socioeconómico, de acuerdo con los modelos de curso de vida, y el índice de masa corporal (IMC) en adultos. Se realizó una revisión en base a las directrices PRISMA. Los estudios se identificaron en las bases de datos MELINE/PubMed, LILACS $y$ Web of Science. Los artículos elegibles investigaron la asociación entre por lo menos un modelo de curso de vida (acumulación de riesgos, periodo crítico o movilidad social) e IMC. Para evaluar la calidad de los artículos seleccionados se aplicó la lista de criterios NOS en cada estudio. Se seleccionaron 11 artículos para la revisión sistemática y siete artículos para el metaanálisis. La puntuación media y la mediana en la lista NOS fueron 6,4, dentro de una puntuación posible de 8. El modelo más utilizado fue el de la movilidad social. En el metaanálisis entre mujeres hubo asociación entre nivel socioeconómico a lo largo de la vida e IMC. La diferencia media (DM) en el IMC fue mayor entre individuos que permanecieron con un nivel socioeconómico bajo a lo largo de la vida, comparado a los que mantuvieron un nivel socioeconómico alto (DM: 2,17; IC95\%: 1,48; 2,86). Antes de esto, la DM en el IMC fue mayor entre individuos con movilidad ascendente, comparado con aquellos que mantuvieron un nivel socioeconómico alto a lo largo de la vida (DM: 1,20; IC95\%: 0,73; 1,68). El riesgo de sobrepeso también fue mayor entre mujeres que mantuvieron un nivel socioeconómico bajo (RR sumario: 1,70; IC95\%: 1,05; 2,74); no obstante, de acuerdo con los criterios GRADE, los estudios presentaron evidencias de calidad muy baja. No se observó asociación en hombres. El nivel socioeconómico bajo en algún momento de la vida está asociado al IMC más alto en la vida adulta.

Revisión; Metaanálisis; Índice de Masa Corporal; Situación Socioeconómica
Submitted on $26 / \mathrm{Jun} / 2018$

Final version rsubmitted on $11 / \mathrm{Feb} / 2019$

Approved on 12/Apr/2019 